\title{
Macrophage activation syndrome in children with systemic juvenile idiopathic arthritis: a retrospective study on 7 patients
}

\author{
Aida Omercahic Dizdarevic ${ }^{*}$, Senka Mesihovic Dinarevic ${ }^{2}$, Velma Selmanovic ${ }^{1}$, Adisa Cengic ${ }^{1}$ \\ From 21st European Pediatric Rheumatology (PReS) Congress \\ Belgrade, Serbia. 17-21 September 2014
}

\section{Introduction}

Macrophage activation syndrome (MAS) is life-threatening complication of rheumatic diseases and is most frequent seen in systemic juvenile idiopathic arthritis (sJIA). Prompt recognition and immediate therapy is life saving.

\section{Objectives}

To review clinical and laboratory data of MAS in 7 children with sJIA.

\section{Methods}

Clinical and laboratory data of 7 patients with MAS, treated in our hospital from January 2008 to December 2013, were analyzed retrospectively.

\section{Results}

Seven children ( 4 females, 3 males) were studied. Two children had incomplete MAS. The underlying disease was not identified in one child. MAS developed during the course of underlying disease (sJIA) in three children. Clinical manifestations at diagnosis included high persistent fever (7), skin rash (6), hepatosplenomegaly (7), lymphadenopathy (6), hemorrhages (5) and central nervous system dysfunction (6). Laboratory data included: high feritin $>10000$ (7), cytopenia (7), abnormal liver function tests (7), hypoalbunaemia (7), hypertriglyceridemia (5), coagulopathy (5), decreased erythrocyte sedimentation rate (5). Macrophage hemophagocytosis were found in 4 bone marrow aspiration. Rota virus was isolated in stool in 3 children. MAS was reccurent in two children (perforin gene done, negative). Six children responded on immunosupressive therapy and are doing well, one child died.

${ }^{1}$ Allergology, Rheumatology and clinical immunology, Children hospital, Sarajevo, Bosnia and Herzegovina

Full list of author information is available at the end of the article

\section{Conclusion}

MAS is rare but serious complication of systemic juvenile idiopathic arthritis in children. It is important to keep in mind suddenly clinical and laboratory disturbanses in children with JIA, to recognise and immediate treat MAS in order to decrease mortality.

\section{Disclosure of interest}

None declared.

\section{Authors' details}

${ }^{1}$ Allergology, Rheumatology and clinical immunology, Children hospital, Sarajevo, Bosnia and Herzegovina. ${ }^{2}$ Cardiology, University Clinic Sarajevo, Children hospital, Sarajevo, Bosnia and Herzegovina.

Published: 17 September 2014

doi:10.1186/1546-0096-12-S1-P218

Cite this article as: Dizdarevic et al:: Macrophage activation syndrome in children with systemic juvenile idiopathic arthritis: a retrospective study on 7 patients. Pediatric Rheumatology 2014 12(Suppl 1):P218.

Submit your next manuscript to BioMed Central and take full advantage of:

- Convenient online submission

- Thorough peer review

- No space constraints or color figure charges

- Immediate publication on acceptance

- Inclusion in PubMed, CAS, Scopus and Google Scholar

- Research which is freely available for redistribution 